\title{
Population Regulation of Gypsy Moth (Lepidoptera: Lymantriidae) by Parasitoids: Does Spatial Density Dependence Lead to Temporal Density Dependence?
}

\author{
C. S. FERGUSON, ${ }^{1}$ J. S. ELKINTON, ${ }^{2}$ J. R. GOULD, ${ }^{3}$ AND W. E. WALLNER ${ }^{4}$
}

Department of Entomology, University of Massachusetts, Amherst, MA 01003

Environ. Entomol. 23(5): 1155-1164 (1994)

ABSTRACT In 1987, four gypsy moth, Lymantria dispar, (L.) densities were established in eight 1-ha plots in western Massachusetts, ranging from 50,000 to $1.4 \mathrm{M}$ neonates per hectare. Two tachinid parasitoid species, Compsilura concinnata (Meigen) and Parasetigena silvestris (Robineau-Desvoidy), exhibited spatial density-dependent parasistism and C. concinnata was the major source of gypsy moth mortality. This study investigated whether spatial density-dependent mortality in 1987 translated into temporal densitydependent mortality of experimental gypsy moth populations created the following year (1988). C. concinnata was responsible for the largest percentage of gypsy moth mortality again in 1988, however, overall mortality caused by C. concinnata in 1988 was considerably less than in 1987. Gypsy moth mortality caused by $P$. silvestris was greater in 1988 . The killing power of either parasitoid in 1988 were not linearly related to the estimated density of the parasitoids produced in the previous year. We saw no evidence for a between-generation numerical response (1-ha scale) of either the generalist parasitoid, $C$. concinnata, or the specialist parasitoid, P. silvestris, between 1987 and 1988 .

KEY WORDS Lymantria dispar, parasitoids, density dependence

AGGREGATIONS OF PARASITOIDS to patches of high-host density may contribute to the stability of host-parasitoid systems (Hassell \& May 1973) and to the success of biological control agents (Beddington et al. 1978). These findings occurred in the context of Nicholson-Bailey models for specialist parasitoids in which the number of hosts parasitized in generation ( $t$ ) determined the number of parasitoids available to attack hosts in the next generation $(t+1)$. The effect of parasitoid aggregation and spatial densitydependent parasitism on the stability of hostparasitoid systems predicted by these earlier studies has been challenged (Murdoch et al. 1984, Reeve \& Murdoch 1985, Murdoch \& Stewart-Oaten 1989). Hassell (1985), Hassell et al. (1987) and Latto \& Hassell (1988) conducted simulations that indicated that spatial densitydependent mortality by generalist parasitoids results in temporal density dependence and regu-

\footnotetext{
1 Current address: Biology Department, Hobart and William Smith Colleges, Geneva, NY 14456.

2 Current address: Department of Entomalogy, University of Massachusetts, Amherst, MA 01003.

${ }^{3}$ Current address: Niles Biological Control Laboratory, USDA-APHIS PPQ, Niles, MI 49120.

4 Current address: Center of Biological Control of Forest Insects and Diseases, Northeast Forest Experiment Station, Hamden, CT 06514.
}

lation of the host population, under some conditions. Dempster \& Pollard (1986) and Stewart-Oaten \& Murdoch (1990) argued that these simulations contained built-in temporal density dependence. Alternative models suggested by Stewart-Oaten \& Murdoch (1990) indicate that spatial heterogeneity of parasitoid attack can destabilize host populations and that spatial density dependence may cause inverse temporal density dependence. The conditions under which spatial density dependence leads to temporal density dependence and the importance of spatial density dependence to population regulation remain unresolved.

In 1987, a strong spatial density-dependent response by a tachinid parasitoid, Compsilura concinnata (Meigen), was demonstrated in experimentally created gypsy moth (Lymantria dispar) field populations ranging from 40,000 to $1.1 \mathrm{M}$ first instars per hectare (Gould et al. 1990). C. concinnata, a multivoltine generalist parasitoid (Culver 1919), was the principal source of gypsy moth larval mortality and the primary reason for the collapse of the experimental populations (Gould et al. 1990). Parasetigena silvestris (Robineau-Desvoidy), a specialist tachinid parasitoid, demonstrated a weak density-dependent response to the experimental gypsy moth populations (Gould et al. 1990). P. silvestris has been 
implicated in the regulation of low-density gypsy moth populations in Europe (Montgomery \& Wallner 1988). These results occurred when native gypsy moth population densities were low, $<10,000$ first instars per hectare.

In recent analyses of $10 \mathrm{yr}$ of gypsy moth density and parasitism data from New Jersey, Williams et al. (1992) concluded that gypsy moth mortality by four of the five dominant parasitoid species, including $P$. silvestris, was directly density dependent. Although, none of the correlations were very strong (Williams et al. 1992). The fifth parasitoid species, C. concinnata, did not exhibit density dependence. Neither $P$. silvestris or C. concinnata exhibited delayed density dependence as indicated by regressions of percentage of parasitism with the density in previous years, and no parasitoid exhibited a strong numerical response to increases in gypsy moth densities (Williams et al. 1992).

We hypothesized that responses of $C$. concinnat $a$ and $P$. silvestris may play a role in suppressing locally dense gypsy moth populations (Gould et al. 1990). However, we do not know if the spatial density dependence documented for either species, translated into temporal density dependence. Therefore, in 1988 we investigated the between-generation numerical response of C. concinnata and $P$. silvestris by experimentally creating gypsy moth populations of 500,000 first instars per hectare in the same augmentation plots established in 1987. We hypothesized that higher rates of gypsy moth parasitism by the specialist $P$. silvestris would occur in the plots receiving the higher gypsy moth densities in the previous year, but no increase in parasitism by the generalist $C$. concinnata would occur, because the latter species requires alternate overwintering hosts.

\section{Materials and Methods}

Study Site. Field studies were conducted at the Cadwell Memorial Forest, a state owned forest located in Pelham and Belchertown, MA, and on the nearby Quabbin Reservoir Forest. In 1988, we used eight l-ha plots established in 1987 for a gypsy moth augmentation study (Gould et al. 1990). The species composition of the overstory and understory vegetation in these plots have been previously described (Gould et al. 1990). Two additional plots, not manipulated in 1987, were established nearby in the Quabbin Forest as controls. Each-1 ha plot consisted of 100 flagged points, evenly spaced, in a 10 by 10 grid (Fig. 1). All plots were separated by at least $500 \mathrm{~m}$.

Collection and Release of Egg Masses. Approximately 30,000 egg masses were collected from wild gypsy moth populations in Queen Annes County, Maryland, in March 1988. The Maryland populations ranged from moderate,
500 egg masses per hectare, to high density, 8,000 egg masses per hectare. Egg masses were transported to the USDA Forest Service Laboratory in Hamden, CT, and stored at $6^{\circ} \mathrm{C}$ until deployed in May. Hatch rate was determined by dividing a random selection of egg masses into five $1 \mathrm{lg}$ samples $( \pm 0.5 \mathrm{mg})$ in individual acrylic mesh packets. The packets were surface sterilized in a $10 \%$ formalin solution to remove viable nuclear polyhedrosis virus from the egg surface, rinsed in tap water for $1 \mathrm{~h}$, dried for $2.5 \mathrm{~h}$, and placed in individual petri dishes and held at room temperature. The petri dishes were checked daily and first instars were counted and removed until hatch ceased ( $P$. Grinberg, Hamden Forest Service Laboratories, personal communication). The mean number of larvae hatching per gram of eggs was used to calculate the number of grams of eggs required to approximate a larval density of 500,000 first instars per hectare.

On 12 May 1988, 100 acrylic packets containing gypsy moth egg masses were deployed in each of the 10 plots coincident with native gypsy moth hatch and oak leaf flush in the plots. The resulting densities $(500,000$ first instars per hectare) were equivalent to the second highest density created in 1987 (see Gould et al. 1990 for density classes). A single packet was stapled at breast height to an overstory tree near each of the 100 flagged points in each plot.

Gypsy Moth Density Estimates. In each plot, gypsy moth densities were monitored using the same techniques used in 1987 (Gould et al. 1990). Frass traps $(n=48)$ (Liebhold \& Elkinton 1988a) were systematically placed in each plot to estimate the density of third to sixth instars per hectare as described by Liebhold \& Elkinton (1988b). Also, $\approx 100$ overstory trees (dbh $>4.0$ $\mathrm{cm})$ in each plot were wrapped with burlap $(\approx 25$ $\mathrm{cm}$ wide) at breast height to provide refuge for older-instar and pupal gypsy moths. Burlapped trees were checked weekly from fourth instar through pupation and the number of larvae in each instar and the number of male and female pupae were recorded. The number of larvae under burlap does not directly translate into the number of larvae per hectare. Therefore, these values were used only to estimate changes in gypsy moth densities for later instars and pupae.

In September 1988, egg masses were counted in each plot using nine 5-m fixed radius circles. No burlapped trees were included in the fixedradius circles. The number of eggs per egg mass was estimated using the methods described by Moore \& Jones (1987). Gypsy moth survival during the 1988 season was compared with gypsy moth survival in 1987 based on the density estimates of gypsy moths in all plots.

Monitoring Gypsy Moth Mortality. One hundred gypsy moth larvae were collected weekly from each plot over a 7-wk period, beginning the 


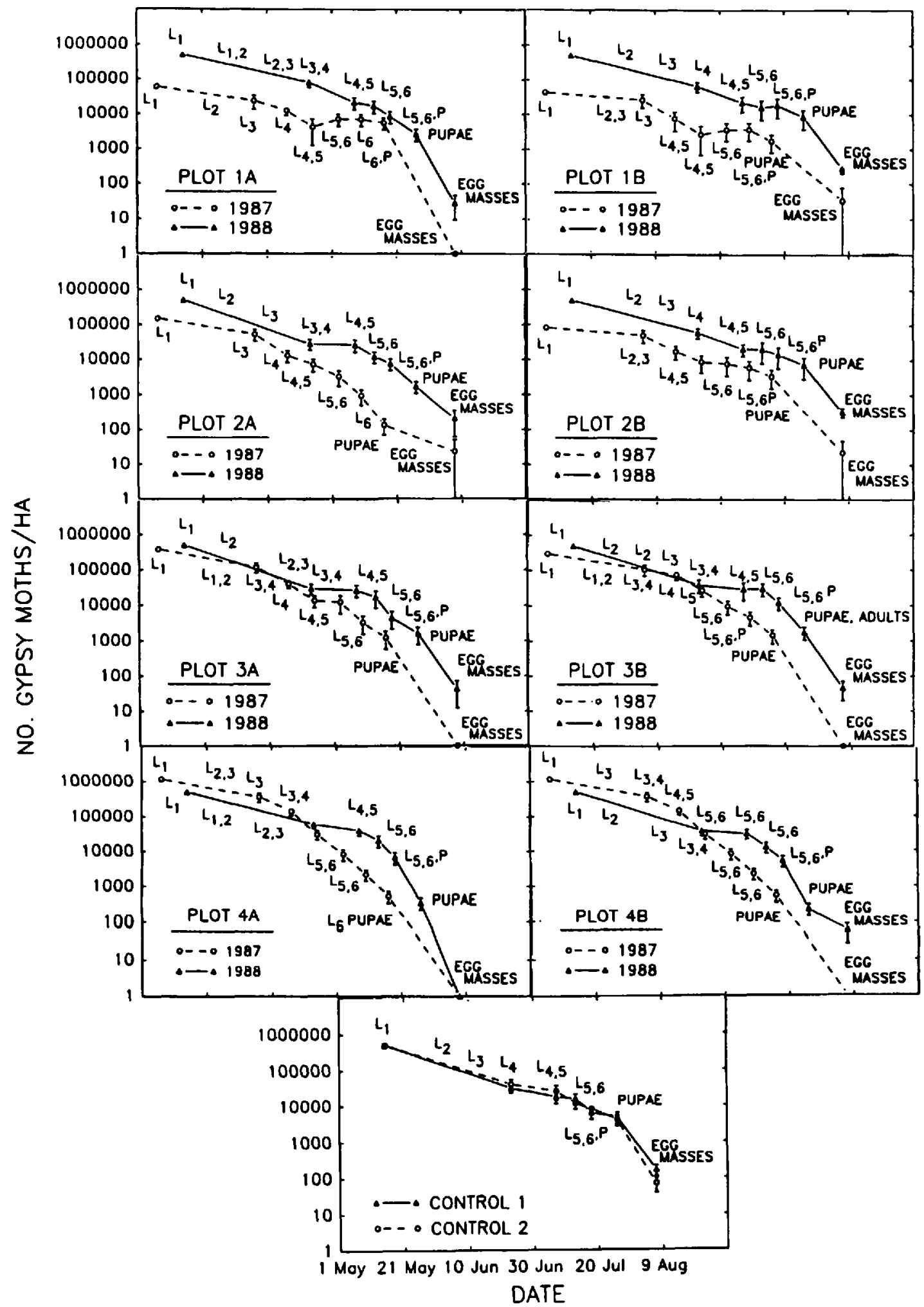

Fig. 1. Density of gypsy moths (moths per hectare) in each 1-ha plot during 1987 and 1988. Larval instars are represented by $\mathrm{L}_{1}-\mathrm{L}_{6}$. Two previously unmanipulated plots were used as control plots in 1988. 
last week of May and continuing to the 2 nd wk in July when pupation started. Early instars were collected from foliage cut from the overstory with pole pruners. Later instars were collected from understory foliage, litter, and tree trunks. All collected larvae were placed individually in 30-ml plastic cups containing artificial diet (Bell et al. 1981) and kept in an outdoor insectary located in Cadwell Forest. Larvae in the insectary were checked weekly and their condition assessed, those living remained in the insectary for subsequent mortality checks. If the fate of the dead larvae was not discernible, they were held for an additional week in the laboratory. If no parasitoids emerged in the additional time, larvae were dissected and checked for unemerged parasitoids and a smear taken to discern occlusion bodies of the nuclear polyhedrosis virus under a phase-contrast microscope at $1,000 \times$ magnification (Woods \& Elkinton 1987). All unexplained mortality was categorized as other. Weekly mortality checks continued until the death or adult emergence of all collected specimens.

Estimating C. concinnata Density. C. concinnata is a multivoltine generalist parasitoid; therefore, it would have attacked alternate hosts for one or more generations since parasitizing gypsy moth in 1987 . We attempted to estimate $C$. concinnata population densities (before our 1988 egg mass release) in five of the 10 plots by placing 50 conical ground-emergence traps (modeled after Polles \& Payne 1972) at 20-m intervals throughout the plots. Additionally, yellow sticky traps $(8.9$ by $12.7 \mathrm{~cm})($ Olson, Pest Management, Amherst, MA) were hung at breast height at 25 points in these plots to monitor $C$. concinnata populations throughout the season (Weseloh 1981). The sticky traps were checked weekly and changed every other week from May through August and all tachinids similar to $C$. concinnata were identified (Sabrosky \& Reardon 1976).

Mortality Analysis. The proportion of mortality caused by each parasitoid was calculated on a weekly basis from the rearing data for each plot (Table 1) (SAS Institute 1987). Because parasitoids can act simultaneously on a single host and host mortality can be attributed to only one parasitoid, a marginal probability of mortality (Royama 1981, Elkinton et al. 1992) caused by a particular parasitoid was calculated using a computer program written by J. Buonaccorsi (Bounaccorsi \& Elkinton 1990). The proportion of individuals surviving the action of each parasitoid (S) was used to calculate the killing power, $k$-value, of that parasitoid; $k=-\log _{10} S$ (Varley et al. 1973). Weekly $k$-values for each cause of death were summed across weeks within each time period. The mortality caused by parasitoids and diseases estimated form the rearing data accounts for only part of the total decline in density
Table 1. Parameters used to calculate period $k$-values hased on the density estimates in all plots, where $k_{i}=$ $-\log _{10} \mathrm{~N} 2 / \mathrm{N} 1$

\begin{tabular}{|c|c|c|c|c|c|}
\hline Period & Date & $\begin{array}{c}\text { Life } \\
\text { stage }^{a}\end{array}$ & $N 1^{b}$ & $N 2$ & $k_{i}$ \\
\hline 1 & $5 / 12-6 / 23$ & $\mathbf{L}_{1}-\mathrm{L}_{3}$ & Neonates/ha & Larvae/ha & $k l$ \\
\hline 2 & $6 / 23-7 / 13$ & $\mathrm{~L}_{3}-\mathrm{L}_{5,6}$ & Larvae/ha & Larvae/ha & $k 2$ \\
\hline 3 & $7 / 13-7 / 26$ & $\mathrm{~L}_{5,6}-\mathrm{P}^{\circ}$ & Larvae/ha & $\begin{array}{l}\text { Pupae/m } \\
\text { burlap }\end{array}$ & $k 3$ \\
\hline $4^{c}$ & $7 / 26-8 / 9$ & P-A & $\begin{array}{r}\text { Pupae/m } \\
\text { burlap }\end{array}$ & $\begin{array}{l}\text { Egg masses/ } \\
\text { ha }\end{array}$ & $k 4$ \\
\hline Season & $5 / 12-8 / 9$ & $\mathrm{~L}_{1}-\mathrm{A}$ & Neonates/ha & $\begin{array}{l}\text { Egg masses/ } \\
\text { ha }\end{array}$ & $\boldsymbol{K}$ \\
\hline
\end{tabular}

a Life stage designations are as follows; $\mathbf{L}=$ larva, $P=$ pupa, $A=$ adult

${ }^{b} N 1=$ initial density, $N 2=$ surviving density, $k=k$-value.

c Indicates period 4 was adjusted by assuming an approximate 50:50 sex ratio and calculating fraction of eclosed females out of total eclosed males and females $=k_{s}$ r

in each time period, the remainder caused by predators and other unknown sources we call residual mortality (Gould et al. 1990). The $k$-value for residual mortality $\left(k_{\text {resid }}\right)$ was calculated as the difference between the $k$-value for total mortality for the time period $\left(k_{i}, i=1,2,3,4\right)$ based on the estimates of density: $k_{i}=-\log _{10}\left(N_{i}\right.$ $\left.+1 / N_{i}\right)$ and the $k$-value for all causes of mortality (parasitoids and disease) estimated from the rearing data. The $k$-value for the last period $\left(k_{4}\right)$ includes a sex-ratio effect, because larval counts include both males and females, whereas only the females produce egg masses. We estimated a $k$-value for sex ratio $k_{s r}=-\log _{10}(f)$ where $f$ is the fraction of the population that was female. An estimate of this fraction was determined from the burlap counts of male and female pupae. A revised estimate of $k_{4}$ was made by subtracting $k_{s r}$ from the estimate of $k_{4}$ based on change in density during this period.

The proportion of gypsy moths surviving weekly after each parasitoid acted was multiplied across the 7-wk larval collection period to obtain gypsy moth mortality caused by each parasitoid for each plot. By percentage of mortality we mean the marginal probability of dying (Royama 1981) expressed as a percentage, which we believe is the best measure of parasitoid impact (Bellows et al. 1992). The percentage of mortality caused by parasitoids were compared by plot between years (1987 versus 1988).

To determine if a between generation numerical response of $C$. concinnata and $P$. silvestris occurred, the estimated $\log _{10}$ number of adult parasites of each species in the 1987 plots was regressed against the observed 1988 percent parasitism (expressed as a $k$-value) of each parasitoid (Abacus Concepts 1990). A significant $(P<$ $0.05)$ positive correlation would be evidence for a between-generation numerical response.

Pupal Survival. Pupal predation in each plot was determined by deploying 48 individual fe- 
Table 2. Fall egg mass counts in 1987 and 1988 and the corresponding 1988 egg densities for all plots including two control (CNT) plots established in 1988

\begin{tabular}{|c|c|c|c|c|c|}
\hline \multirow{2}{*}{ Plot } & \multicolumn{2}{|c|}{ Egg masses/ha } & \multirow{2}{*}{$\frac{\mathrm{Eggs}_{\mathrm{ha}}{ }^{a}}{1988}$} & \multicolumn{2}{|c|}{$95 \% \mathrm{CI}$} \\
\hline & 1987 & 1988 & & Lower & Upper \\
\hline IA & 0 & 28 & 4,383 & 4,277 & 4,711 \\
\hline IB & 34 & 283 & 42,183 & 42,120 & 4,253 \\
\hline $2 A$ & 23 & 198 & 104,440 & 104,217 & 105,688 \\
\hline 2B & 23 & 325 & 50,127 & 50,062 & 50,491 \\
\hline $3 A$ & 0 & 46 & 7,922 & 7,850 & 8,327 \\
\hline $3 B$ & 0 & 42 & 12,259 & 12,137 & 12,943 \\
\hline $4 A$ & 0 & 0 & 0 & 0 & 0 \\
\hline $4 B$ & 0 & 56 & 7,698 & 7,640 & 8,021 \\
\hline CNT 1 & - & 169 & 24,801 & 24,739 & 25,147 \\
\hline CNT 2 & - & 70 & 31,320 & 31,133 & 32,369 \\
\hline
\end{tabular}

0 , No egg masses were found. - Indicates that two control plots (CNT I and 2) were not sampled in 1987.

a The number of eggs per hectare was calculated using the Moore \& Jones (1987) regression equation.

male gypsy moth pupae, adhered to small burlap pieces with beeswax, in each plot for a period of $3 \mathrm{~d}$ (Smith \& Lautenschlager 1981). The pupae were placed on the ground at the same flagged points in all plots. On day 3 , the pupae were examined and their fate determined based on the type of feeding damage we observed (Smith \& Lautenschlager 1981). The goodness-of-fit of the observed pupal survival in each plot to pupal survival in the same plots in 1987 was tested using the chi-square test statistic (SAS Institute 1987).

\section{Results}

Gypsy Moth Density Estimates. Final gypsy moth densities were considerably higher in 1988 than in 1987 in seven of the eight field plots based on fall egg mass counts (Table 2). Plot designations are the same as those used by Gould et al. (1990). In 1988, the most substantial drop in gypsy moth density occurred between late instars, pupal and adult stages (Fig. 1). The rate of decline during these life stages was sim- ilar to the decline observed during the same life stages in 1987. However, the 1987 gypsy moth populations also exhibited substantial drops in density during midlarval stages $\left(\mathrm{L}_{3}-\mathrm{L}_{5}\right)$. Survivorship curves were almost identical for the gypsy moth populations in the two control plots that had not been manipulated in 1987 (Fig. 1).

Mortality Analysis. The same parasitoid species were recovered from gypsy moth larvae in both years, two dipeteran parasites, C. concinnata and $P$. silvestris, and two hymenopteran parasites, Cotesia melanoscela Ratzburg (Braconidae) and Phobocampe disparis Veireck (Ichneumonidae). Total gypsy moth mortality was higher in the 1987 plots than in the same plots in 1988 based on analysis of the rearing data (Table 3) and coincided with decreased gypsy moth survivorship in 1987. Total gypsy moth mortality in the two control plots were comparable to levels of gypsy moth mortality observed in the other eight plots, although control plot 1 (CNTl) did have the lowest gypsy moth mortality out of the 101988 plots.

Table 3. Gypsy moth percentage of mortality caused by natural occurring parasitoids within experimental plots in 1987 and 1988

\begin{tabular}{|c|c|c|c|c|c|c|c|c|c|c|}
\hline \multirow{2}{*}{ Plot } & \multicolumn{2}{|c|}{ Compsilura } & \multicolumn{2}{|c|}{ Parasetigena } & \multicolumn{2}{|c|}{ Cotesia } & \multicolumn{2}{|c|}{ Phobocampe } & \multicolumn{2}{|c|}{ Total } \\
\hline & 1987 & 1988 & 1987 & 1988 & 1987 & 1988 & 1987 & 1988 & 1987 & 1988 \\
\hline $1 \mathrm{~A}$ & 38.3 & 31.5 & 16.8 & 21.5 & 2.3 & 12.9 & 16.8 & 25.3 & 80.0 & 76.5 \\
\hline IB & 45.0 & 41.4 & 14.9 & 10.3 & 6.7 & 13.6 & 25.9 & 2.5 & 85.9 & 74.5 \\
\hline $2 \mathrm{~A}$ & 72.5 & 46.6 & 6.7 & 22.1 & 8.8 & 6.8 & 22.4 & 5.8 & 90.0 & 85.9 \\
\hline $2 \mathrm{~B}$ & 77.1 & 51.7 & 6.7 & 14.3 & 10.9 & 9.8 & 6.7 & 21.2 & 92.9 & 88.1 \\
\hline $3 A$ & 88.0 & 45.7 & 10.9 & 24.1 & 8.8 & 2.2 & 4.5 & 12.0 & 96.0 & 81.1 \\
\hline 3B & 90.9 & 56.5 & 10.9 & 13.0 & 12.9 & 7.5 & 8.8 & 9.4 & 98.4 & 78.8 \\
\hline $4 \mathrm{~A}$ & 94.6 & 48.0 & 22.4 & 16.4 & 12.9 & 20.8 & 8.8 & 21.2 & 98.8 & 86.7 \\
\hline $4 \mathrm{~B}$ & 91.9 & 42.7 & 2.4 & 14.9 & 10.9 & 12.0 & 0.0 & 8.9 & 99.6 & 77.3 \\
\hline CNT1 & - & 32.0 & - & 20.6 & - & 1.3 & - & 11.1 & - & 69.0 \\
\hline CNT2 & - & 26.3 & - & 23.2 & - & 5.0 & - & 12.0 & - & 78.6 \\
\hline Mean $^{a}$ & 74.8 & 45.5 & 11.5 & 17.1 & 9.3 & 10.7 & 11.7 & 13.3 & 92.7 & 81.1 \\
\hline
\end{tabular}

Mortality was computed as $\left(1-\prod_{i=1}^{7}\left(1-m_{a i}\right)\right)$ where $m_{a}$ is the marginal probability of dying from agent $A$ in week $i$ over a 7-wk period and total mortality $=1$ - the product of the total proportion of gypsy moths surviving after each parasitoid acted. Total mortality will not equal the sum of the parasitoid mortality. See Gould et al. (1990), Elkinton et al. (1992) for details.

${ }^{a}$ Mean mortality was calculated on the eight plots used in both 1987 and 1988. 
Table 4. The killing power ( $k$-value) of mortality agents during five periods in 1987 and 1988

\begin{tabular}{|c|c|c|c|c|c|c|c|c|c|c|}
\hline & \multicolumn{8}{|c|}{ Plots } & \multicolumn{2}{|c|}{ Controls } \\
\hline & $1 \mathrm{~A}$ & $1 B$ & $2 A$ & $2 \mathrm{~B}$ & $3 A$ & 3B & $4 \mathrm{~A}$ & $4 B$ & 1 & 2 \\
\hline$K$ & 4.29 & 3.27 & 3.42 & 3.18 & 4.05 & 4.12 & 5.79 & 3.95 & 3.48 & 3.84 \\
\hline$k 1$ & 0.84 & 0.90 & 1.27 & 0.92 & 1.24 & 1.16 & 1.00 & 1.11 & 1.18 & 1.08 \\
\hline$k$-Comp & 0.03 & 0.05 & 0.04 & 0.03 & 0.03 & 0.03 & 0.10 & 0.03 & 0.03 & 0.02 \\
\hline$k$-Cote & 0.01 & 0.01 & 0.00 & 0.00 & 0.01 & 0.01 & 0.01 & 0.02 & 0.00 & 0.01 \\
\hline$k$-Phob & 0.03 & 0.00 & 0.04 & 0.01 & 0.03 & 0.01 & 0.01 & 0.02 & 0.01 & 0.02 \\
\hline$k$-Para & 0.02 & 0.01 & 0.01 & 0.01 & 0.00 & 0.01 & 0.02 & 0.01 & 0.01 & 0.02 \\
\hline$k$-Unexp & 0.01 & 0.05 & 0.07 & 0.01 & 0.01 & 0.02 & 0.04 & 0.01 & 0.02 & 0.11 \\
\hline$k$-Resid & 0.74 & 0.78 & 1.11 & 0.86 & 1.16 & 1.08 & 0.82 & 1.02 & 1.11 & 0.90 \\
\hline$k 2$ & 0.66 & 0.61 & 0.37 & 0.48 & 0.24 & 0.12 & 0.46 & 0.48 & 0.32 & 0.55 \\
\hline$k$-Comp & 0.13 & 0.18 & 0.28 & 0.24 & 0.33 & 0.24 & 0.27 & 0.22 & 0.14 & 0.12 \\
\hline$k$-Cote & 0.06 & 0.06 & 0.05 & 0.03 & 0.02 & 0.00 & 0.09 & 0.03 & 0.01 & 0.01 \\
\hline$k$-Phob & 0.12 & 0.01 & 0.07 & 0.01 & 0.02 & 0.05 & 0.09 & 0.02 & 0.04 & 0.03 \\
\hline$k$-Para & 0.09 & 0.04 & 0.06 & 0.10 & 0.06 & 0.11 & 0.06 & 0.06 & 0.09 & 0.09 \\
\hline$k$-Unexp & 0.16 & 0.20 & 0.32 & 0.41 & 0.17 & 0.26 & 0.27 & 0.23 & 0.17 & 0.23 \\
\hline$k$-Resid & 0.10 & 0.12 & -0.41 & -0.31 & -0.36 & -0.54 & -0.32 & -0.08 & -0.13 & 0.07 \\
\hline$k 3$ & $0.8 \mathrm{I}$ & 0.27 & 0.85 & 0.43 & 1.03 & 1.22 & 1.77 & 1.74 & 0.54 & 0.46 \\
\hline$k$-Comp & $0.0 \mathrm{I}$ & 0.01 & 0.00 & 0.02 & 0.04 & 0.01 & 0.07 & 0.03 & 0.01 & 0.02 \\
\hline$k$-Cote & 0.05 & 0.00 & 0.02 & 0.00 & 0.01 & 0.01 & 0.07 & 0.01 & 0.01 & 0.01 \\
\hline$k$-Phob & 0.00 & 0.00 & 0.00 & 0.00 & 0.00 & 0.00 & 0.00 & 0.00 & 0.00 & 0.00 \\
\hline$k$-Para & 0.10 & 0.04 & 0.07 & 0.07 & 0.09 & 0.10 & 0.07 & 0.06 & 0.09 & 0.07 \\
\hline$k$-Unexp & 0.17 & 0.13 & 0.14 & 0.24 & 0.19 & 0.21 & 0.07 & 0.16 & 0.27 & 0.24 \\
\hline$k$-Resid & 0.48 & 0.09 & 0.62 & 0.10 & 0.70 & 0.89 & 1.49 & 1.48 & 0.16 & 0.12 \\
\hline$k_{\mathrm{sr}}$ & 0.85 & 0.49 & 0.44 & 0.60 & 0.30 & 0.48 & 0.60 & 0.15 & 0.51 & 0.44 \\
\hline$k 4$ & 1.13 & 1.00 & 0.49 & 0.75 & 1.24 & 1.14 & 1.96 & 0.47 & 0.93 & 1.31 \\
\hline
\end{tabular}

1: 5/12-6/23 (k1), period 2: 6/23-7/13 (k2), period 3:7/13-7/26 $(k 3)$, period 4: 7/26-8/19 $(k 4)$ and the entire season: 5/12-8/9 $(K)$ in 1988 plots.

Comp, Compsilura concinnata, cote, Cotesia melanoscelus, phob, Phobacampe disparis, para, Parasetigena silvestris, unexp, unexplained rearing mortality, and resid, residual mortality not accounted for by rearing.

The generalist parasitoid, $C$. concinnata, caused the largest percentage of gypsy moth mortality in both 1987 and 1988 (Table 3). However, in 1988, gypsy moth mortality caused by $C$. concinnata was considerably less than mortality caused by C. concinnata in 1987 (mean mortal-

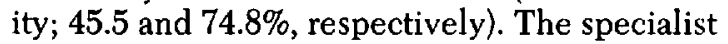
tachinid parasitoid, $P$. silvestris, caused less overall mortality to gypsy moth than $C$. concinnata in both years, but mortality caused by $P$. silvestris was higher in 1988 than in 1987 (mean mortality; 17.1 and $11.5 \%$, respectively). Parasitism by $P$. silvestris was not higher in plots receiving higher gypsy moth densities in 1987 (Table 3). In the two control plots, mortality caused by $P$. silvestris was comparable to mortality caused by $C$. concinnata.

The mean percentage of mortality attributed to C. melanoscela and P. disparis, neither of which displayed a density-dependent response in 1987, was comparable in both years (Table 3). The contribution of each of these parasitoids to gypsy moth mortality varied considerably between plots in 1988.

To assess the relative importance of each parasitoid on different life stages of gypsy moth, the killing power ( $k$-values) of each agent was compared during four discrete time periods (Table 4). In all plots, the largest contribution to period $1 k$-values $(k 1)$, which includes early instars $\left(\mathrm{L}_{1-}^{-}\right.$ $\mathrm{L}_{3}$ ), was residual mortality. Because residual mortality measures mortality not accounted for by rearing, it appears that either dispersal (Le- onard 1971) or predation (Campbell 1969) may be important in early instar losses. Overall, mortality caused by parasitism was negligible during period 1.

In period 2, when gypsy moths were primarily in mid-larval stages $\left(\mathrm{L}_{3}-\mathrm{L}_{5}\right)$, residual mortality was inconsequential, which implies that rearing mortality accurately reflected field mortality during this period. The largest contribution to period $2 k$-values $(k 2)$ was by $C$. concinnata (Table 4). Period $3 k$-values $(k 3)$ were greater than $k 2$ values in seven of the 10 plots, which coincides with declines in gypsy moth survivorship during later instar and pupal stages (Table 4; Fig. 2). P. silvestris contributed the most to period $3 k$-values in 1988 and contrasts with 1987, when $C$. concinnata remained the primary mortality agent acting during period 3 (Gould et al. 1990). Residual mortality was the largest component of $k 3$ and may be attributed in part to predation (Table 4). A variety of invertebrates was observed under the burlap bands during this time period. Most noticeable were the carabid beetles, Calosoma spp., immature staphilinids, pentatomids, ants, and spiders. We made no attempt to measure their impact.

Vertebrate predation of the last instars and pupae was not directly assessed but was probably a contributing factor to the period $3 k$-value. Unexplained mortality was also an important component of $k 2$ and $k 3$ and probably reflects factors associated with handling field collected larvae. 


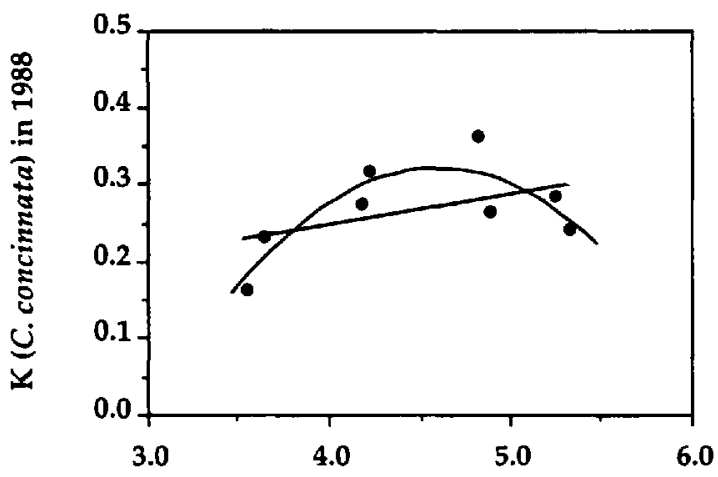

$\log _{10}$ density of $C$. concinnata in 1987

Fig. 2. Regression of the $k$-value for $C$. concinnata in 1988 on $\log _{10}$ density of $C$. concinnata in 1987 ( $Y=$ $0.087+0.040(\mathrm{X}) ; R^{2}=0.2209 ; P=0.240, Y=-2.38+$ $\left.1.17(\mathrm{X})-0.13\left(\chi^{2}\right) ; R^{2}=0.728 ; P=0.0384\right)$.

Small mammal predation of gypsy moth pupae probably contributed to the disappearance of pupae under burlap in period 4 (Campbell \& Sloan 1977 a, b; Elkinton et al. 1989). Pupal survival in 1988 was not significantly different from pupal survival in $1987\left(\chi^{2}=0.50\right)$ based on the pupal predation of field deployed female pupae (Table 5).

Regression Analysis. The killing power of $C$. concinnata in 1988 was not linearly related to the density of hosts parasitized by C. concinnata in $1987\left(R^{2}=0.2209, P=0.240\right)$ (Fig. 2). These results suggest that the generalist parasitoid, $C$. concinnata, did not exhibit a between-generation numerical response as we expected given the requirement of this species for alternate hosts. However, a quadratic equation $(Y=-2.38+$ $\left.1.17 X-0.13 X^{2}\right)$ provided a better fit for this data $\left(R^{2}=0.728, P=0.0384\right.$ ) suggesting a weak numerical response.

The killing power of $P$. silvestris in 1988 also was not related by linear or by polynomial regression to the density of the specialist parasitoid, $P$. silvestris, in $1987\left(R^{2}=0.052, P=\right.$ 0.577 ) (Fig. 3). The lack of correlation between the density of $P$. silvestris in 1987 and the killing power of the same parasitoid in 1988 in conjunc-

Table 5. Survival of female gypsy moth pupae in 1987 and 1988 when deployed over a 3 -d period

\begin{tabular}{ccc}
\hline \multirow{2}{*}{ Plot } & \multicolumn{2}{c}{ Proportion of pupae surviving } \\
\cline { 2 - 3 } & 1987 & 1988 \\
\hline IA & 0.27 & 0.56 \\
IB & 0.34 & 0.65 \\
$2 \mathrm{~A}$ & 0.34 & 0.73 \\
$2 \mathrm{~B}$ & 0.50 & 0.19 \\
$3 \mathrm{~A}$ & 0.36 & 0.40 \\
$3 \mathrm{~B}$ & 0.60 & 0.50 \\
$4 \mathrm{~A}$ & 0.38 & 0.15 \\
4B & 0.62 & 0.08 \\
Mean & $0.43 \pm 0.12$ & $0.41 \pm 0.23$ \\
\hline
\end{tabular}

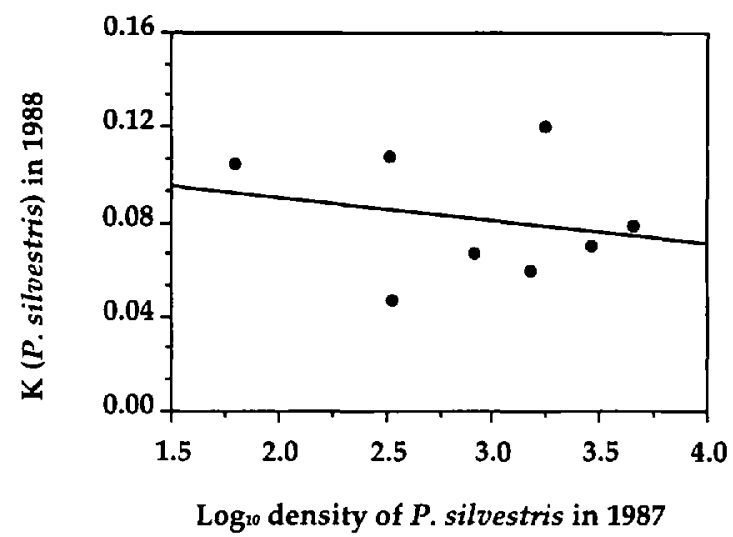

Fig. 3. Regression of the $k$-value for $P$. silvestris in 1988 on $\log _{10}$ density of $P$. silvestris in $1987(Y=0.11-$ $\left.0.0098(\mathrm{X}) ; R^{2}=0.052 ; P=0.577\right)$.

tion with no increase in parasitism by $P$. silvestris in plots receiving higher gypsy moth densities in 1987 suggests that a between-generation numerical response by the specialist parasitoid did not occur and does not support our hypothesis.

\section{Discussion}

Although each of the 10 plots had approximately equivalent initial gypsy moth densities $(500,000$ neonates per hectare), their final densities were quite variable, ranging from 0 egg masses per hectare in plot $4 \mathrm{~A}$ to 325 egg masses per hectare in plot $2 \mathrm{~B}$. These results contrast with the final density estimates from 1987, where all experimental gypsy moth populations collapsed, with five of the eight plots having zero egg masses per hectare in postseason counts. The three plots with the greater number of egg masses in 1988, (1B, 2A, and $2 \mathrm{~B}$ ) were also the only plots to have egg masses in the 1987 postseason count. The estimated number of larvae in these three plots at the beginning of 1988 was 20,000 larvae per hectare in $1 B$ and 13,000 larvae per hectare in each of $2 \mathrm{~A}$ and $2 \mathrm{~B}$ (Moore \& Jones 1987). These numbers are negligible compared with the 500,000 neonates per hectare added to these plots in 1988.

Site conditions could not have contributed to the divergent gypsy moth survival between years because the same plots were used in both years (Campbell \& Sloan 1977b). However, environmental conditions were different between 1987 and 1988 and the effect of temperature and moisture on the developmental rate of both host and parasitoid populations needs to be more fully addressed. From examination of the minimum and maximum temperatures during both years it appears that the duration of the pupal period in 1988 was shorter than in 1987 by $2 \mathrm{~d}$ as predicted by the temperature-dependent growth model of 


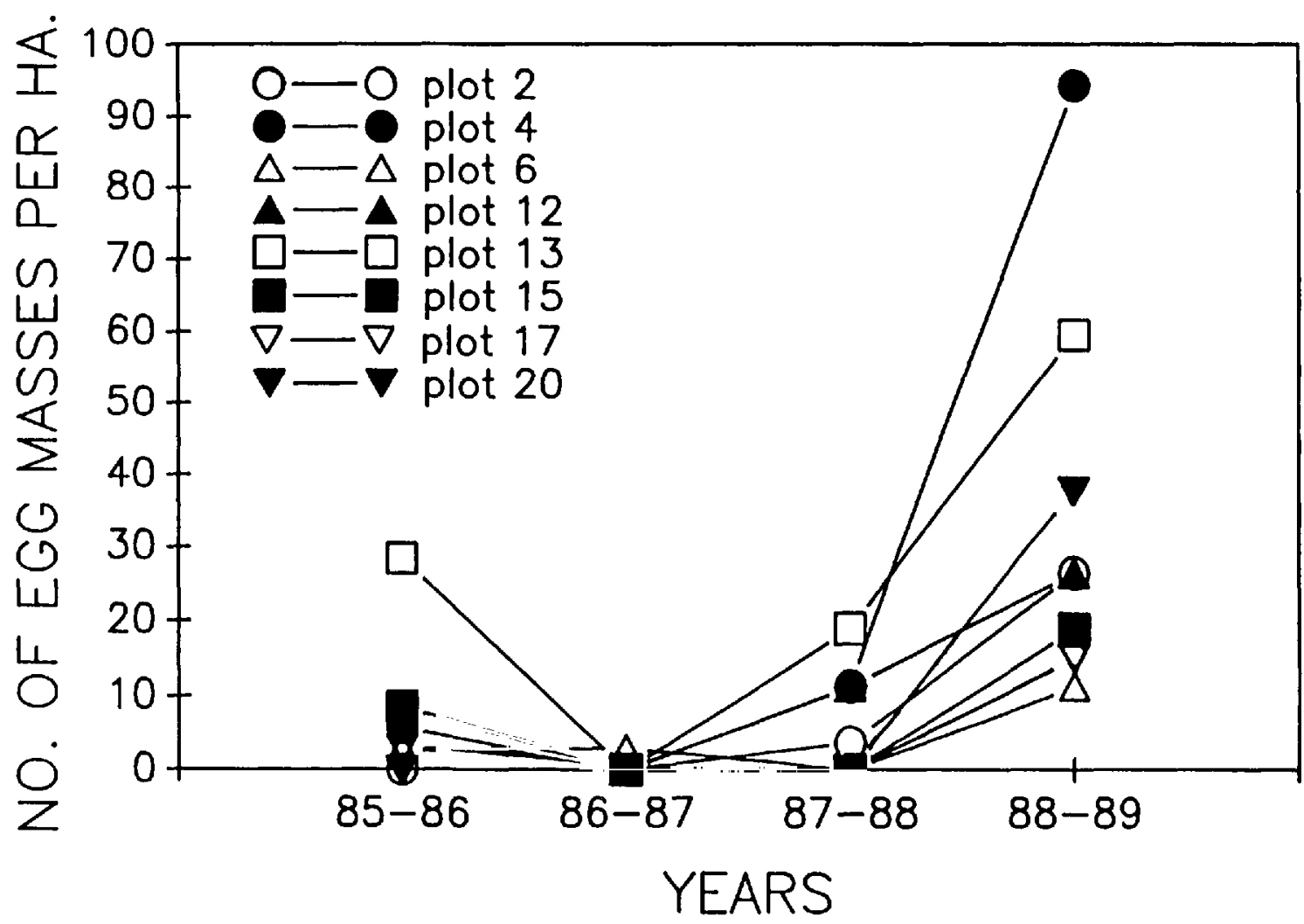
1989.

ig. 4. Gypsy moth population trends (egg masses per hectare) in western Massachusetts from 1985 through

Casagrande et al. (1987). A shorter pupal period in conjunction with equivalent daily rates of predation on pupae (Table 5) could result in higher survival to the adult stage.

Another explanation for the difference in the number of gypsy moths surviving in 1987 and in 1988 would be the difference in parasitism levels in each year. In both years, the same four parasitoid species were obtained from field-collected gypsy moth larvae, however, overall mortality from parasitoids differed between years. C. concinnata caused the majority of mid-larval (between third and fifth instar) gypsy moth mortality in 1987 and 1988. In 1987, C. concinnata was also the primary mortality agent of last-instar and pupal gypsy moths, but $P$. silvestris was the primary mortality agent in this same period (period 3 ) in 1988. The reduction in parasitism by $C$. concinnata in 1988 may reflect the current regional increase of gypsy moth densities (Fig. 4). Consequently, the strong spatial density-dependent response of $C$. concinnata in 1987 may be damped out in 1988 because of less contrast between experimental plots and surrounding gypsy moth densities. In general, the prevalence of $C$. concinnata in 1988 supports past findings that it is the dominant parasitoid in this geographic region (Barbosa et al. 1975, Reardon 1976), especially in terms of percentage of parasitism.
The effect alternate-host densities may have on the density and distribution of C. concinnata has not been documented. Berryman (1991) suggests that a generalist parasitoid may switch to more abundant alternate hosts resulting in a firstorder negative feedback or spatial density dependence. C. concinnata are multivoltine generalists (four generations per year) with one generation developing when gypsy moths are vulnerable to parasitism (Culver 1991, Sabrosky \& Reardon 1976, Weseloh 1982). The high density of $C$. concinnata emerging from parasitized gypsy moth hosts in 1987 would require an equally high density of alternate hosts within our 1-ha plots in order to overwinter. The fact that no C. concinnata were recovered from either ground emergence traps or sticky traps located inside five of the plots may mean that $C$. concinnata dispersed away from our experimental plots in search of alternate hosts. We did not attempt to measure the density of alternate hosts but we did observe that another host of $C$. concinnata, the forest tent caterpillar, Malacosoma disstria, was abundant in our 1988 plots at the same time that gypsy moths were vulnerable to parasitism by $C$. concinnata.

We did not anticipate a between-generation numerical response by the multivoltine generalist parasitoid, $C$. concinnata. The fact that a qua- 
dratic model fit the data better suggests that there are lower and upper limits to the number of gypsy moths $C$. concinnata can parasitize as was suggested by Gould et al. (1990) in relation to the density-dependent response of C. compsilura in 1987. In conjunction, Berryman et al. (1987) would predict a nonlinear second-order negative feedback for a multivoltine generalist. We did predict a between-generation numerical response by $P$. silvestris because it is a univoltine specialist parasitoid and synchronized with gypsy moth, but our results indicate that parasitism in gypsy moth populations, at least on the l-ha scale, is dominated by spatial responses and between-year effects are minor (Elkinton et al. 1990). This raises the question of what is the most appropriate spatial scale to conduct such a study (Heads \& Lawton 1983). It is possible that temporal density dependence would be observed on a larger regional scale. Our study illustrates a methodology for examining temporal density dependence experimentally as an alternative or supplement to the classical approach of following populations over a long period of years.

\section{Acknowledgments}

We are very grateful to C. Boettner and G. Boettner for field and technical assistance. We are also grateful to M. Abbell, S. Ambs, J. Catlin, E. Clark, G. Davis, L. McGlinchey, H. Nichols, B. Postier, W. Stratz, and J. Wells for field assistance and A. Bonser, C. Kish, and K. Murray for assistance in the laboratory. We thank A. DeVito for field assistance and $\mathbf{P}$. Grinberg for research assistance and data entry from the Northeastern Forest Experiment Station in Hamden, CT. We also thank personnel from Maryland Forest Pest Management for their assistance in collecting egg masses, D. Arganbright of the Department of Forestry and Wildlife at the University of Massachusetts for access to Cadwell Forest, and the Massachusetts District Commission for access to the Quabbin Reservoir. This research was supported by a cooperative agreement with U.S. Forest Service 23-142.

\section{References Cited}

Abacus Concepts. 1990. Super ANOVA. Berkeley, CA.

Barbosa, P., J. L. Capinera \& E. A. Harrington. 1975. The gypsy moth parasitoid complex in western Massachusetts: a study of parasitoids in areas of high and low host density. Environ. Entomol. 4: 842-846.

Beddington, J. R., C. A. Free \& J. H. Lawton. 1978. Characteristics of successful natural enemies in models of biological control of insect pests. Nature (Lond.) 273: 513-519.

Bell, R. A., C. D. Owens, M. Shapiro \& J. R. Tardif. 1981. Development of mass-rearing technology, pp. 599-633. In C. C. Doane \& M. L. McManus [eds.], The gypsy moth: research toward integrated pest management. U.S. Dep. Agric. Tech. Bull. 1584 .
Bellows, T. S., R. G. Van Driesche \& J. S. Elkinton. 1992. Life-table construction and analysis in evaluation of natural enemies. Annu. Rev. Entomol. 37: 587-614.

Berryman, A. A. 1991. Gypsy moth in North America: a case of successful biological control? Tree 6: 110-111.

Berryman, A. A., N. C. Strenseth \& A. S. Isaev. 1987. Natural regulation of herbivorous forest insect populations. Oecologia (Berl.) 71: 174-184.

Buonaccorsi, J. P. \& J. S. Elkinton. 1990. Estimation of contemporaneous mortality factors. Res. Popul. Ecol. 32: 151-171.

Campbell, R. W. 1969. Studies on gypsy moth population dynamics, pp. 29-34. In Proceedings, Forest Insect Population Dynamics Workshop, 1967. U.S. Dep. Agric. For. Serv. Res. Pap. NE 125

Campbell, R. W. \& R. J. Sloan. 1977a. Natural regulation of innocuous gypsy moth populations. Environ. Entomol. 6: 315-322.

1977b. Release of gypsy moth populations from innocuous levels. Environ. Entomol. 6: 323-330.

Casagrande, R. A., P. A. Logan \& W. E. Wallner. 1987. Phenological model for gypsy moth, Lymantria dispar (Lepidoptera: Lymantriidae), larvae and pupae. Environ. Entomol. 16: 556-562.

Culver, J. J. 1919. A study of Compsilura concinnata, an imported Tachinid parasite of the gypsy moth and the brown-tail moth. U.S. Dep. Agric. Bull. 776: 1-26.

Dempster, J. P. \& E. Pollard. 1986. Spatial heterogeneity, stochasticity and the detection of density dependence in animal populations. Oikos 46: 413416.

Elkinton, J. S., J. P. Buonaccorsi, T. S. Bellows \& R. G. Van Driesche. 1992. Marginal attack rate, k-values and density dependence in the analysis of contemporaneous mortality factors. Res. Popul. Ecol. 34: $29-44$

Elkinton, J. S., J. R. Gould, A. M. Liebhold, H. R. Smith \& W. E. Wallner. 1989. Are gypsy moth populations in North America regulated at low density? pp. 233-249. In W. E. Wallner [ed.], The Lymantriidae: comparisons of features of new and old world tussock moths. U.S. Dep. Agric. For. Serv. Gen. Tech. Rep. NE-123.

Elkinton, J. S., J. R. Gould, C. S. Ferguson, A. M. Liebhold \& W. E. Wallner. 1990. Experimental manipulation of gypsy moth density to assess impact of natural enemies, pp. 275-287. In A. Watt, M Hunter, S. Leather \& N. Kidd [eds.], Population dynamics of forest insects. Intercept, Hampshire, U.K.

Gould, J. R., J. S. Elkinton \& W. E. Wallner. 1990 Density dependent suppression of experimentally created gypsy moth, Lymantria dispar (Lepidoptera: Lymantriidae), populations by natural enemies. J. Anim. Ecol. 59: 213-234.

Hassell, M. P. 1985 . Insect natural enemies as regulating factors. J. Anim. Ecol. 54: 323-334.

Hassell, M. P. \& R. M. May. 1973. Stability in insect-host parasite models. J. Anim. Ecol. 42: 693726.

Hassell, M. P., T.R.E. Southwood \& P. M. Reader. 1987. The dynamics of the viburnum whitefly (Aleurotrachelus jelinekii): a case study of population regulation. J. Anim. Ecol. 56: 283-300. 
Heads, P. A. \& J. H. Lawton. 1983. Studies on the natural enemy complex of the holly leaf-miner: the effects of scale on the detection of aggregative responses and the implications for biological control. Oikos 40: 267-276.

Latto, J. \& M. P. Hassell. 1988. Generalist predators and the importance of spatial density dependence. Oecologia (Berl.) 77: 375-377.

Leonard, D. E. 1971. Air-borne dispersal of larvae of the gypsy moth and its influence on concepts of control. J. Econ. Entomol. 64: 638-641.

Liebhold, A. M. \& J. S. Elkinton. 1988a. Techniques for estimating the density of late-instar gypsy moth, Lymantria dispar (Lepidoptera: Lymantriidae), populations using frass drop and frass production measurements. Environ. Entomol. 17: 381-384.

1988b. Estimating the density of larval gypsy moth, Lymantria dispar (Lepidoptera: Lymantriidae), using frass drop and frass production measurements: sources of variation and sample size. Environ. Entomol. 17: 385-390.

Montgomery, M. E. \& W. E. Wallner, 1988. The gypsy moth a westward migrant. In A. A. Berryman [ed.], Dynamics of forest insect populations, patterns, causes and implications. Plenum, New York.

Moore, K.E.B. \& C. G. Jones. 1987. Field estimation of fecundity of gypsy moth (Lepidoptera: Lymantriidae). Environ. Entomol. 16: 165-167.

Murdoch, W. W. \& A. Stewart-Oaten. 1989. Aggregation by parasitoids and predators: effects on equilibrium and stability. Am. Nat. 134: 288-310.

Murdoch, W. W., J. D. Reeve, C. B. Huffaker \& C. E. Kennett. 1984. Biological control of scale insects and ecological theory. Am. Nat. 123: 371-392.

Polles, S. G. \& J. A. Payne. 1972. An improved emergence trap for adult pecan weevils. J. Econ. Entomol. 65: 1529.

Reardon, R. C. 1976. Parasite incidence and ecological relationships in field populations of gypsy moth larvae and pupae. Environ. Entomol. 5: 981-987.

Reeve, J. D. \& W. W. Murdoch. 1985. Aggregation by parasitoids in the successful control of the Cali- fornia red scale: a test of theory. J. Anim. Ecol. 54: $797-816$.

Royama, T. 1981. Evaluation of mortality factors in insect life table analysis. Ecol. Monogr. 5: 495-505.

Sabrosky, C. W. \& R. C. Reardon. 1976. Tachinid parasites of the gypsy moth, Lymantria dispar, with keys to adults and puparia. Misc. Publ. Entomol. Soc. Am. 10: 126.

SAS Institute. 1987. SAS user's guide: statistics. SAS Institute, Cary, NC.

Smith, H. R. \& R. A. Lautenschlager. 1981. Gypsy moth predators, pp. 96-124. In C. C. Doane \& M. L. McManus [eds.], The gypsy moth: research toward integrated pest management. U.S. Dep. Agric. Tech. Bull. 1584.

Stewart-Oaten, A. \& W. W. Murdoch. 1990. Temporal consequences of spatial density dependence. J. Anim. Ecol. 59: 1027-1045.

Varley, G. C., G. R. Gradwell \& M. P. Hassell. 1973. Insect population ecology: an analytical approach. University of California Press, Berkeley.

Weseloh, R. M. 1981. Relationship between colored sticky panel catches and reproductive behavior of forest tachinid parasitoids. Environ. Entomol. 10: 131-135.

1982. Implications of tree microhabitat preferences of Compsilura concinnata, Diptera: Tachinidae, for its effectiveness as a gypsy moth, Lymantria dispar, parasitoid. Can. Entomol. 114: 617-622.

Williams, D. W., R. W. Fuester, W. W. Metterhouse, R. J. Balaam, R. H. Bullock, R. J. Chianese \& R. C. Reardon. 1992. Incidence and ecological relationships of parasitism in larval populations of Lymantria dispar (Lepidoptera: Lymantriidae). Biol. Control 2: 35-43.

Woods, S. A. \& J. S. Elkinton. 1987. Bimodal patterns of mortality from nuclear polyhedrosis virus in gypsy moth (Lymantria dispar) populations. J. Invertebr. Pathol. 50: 151-157.

Received for publication 2 November 1993; accepted 5 May 1994. 